\title{
E-LEARNING AKSARA JAWA DENGAN INDEX CARD MATCH (ICM) BERBASIS WEB
}

\author{
${ }^{1}$ Andri Putro Pamungkas, ${ }^{2}$ Dedih, ${ }^{3}$ Dwi Agus Suprapto \\ STMIK Kharisma Karawang, Teknik Informatika ${ }^{1,3}$, Sistem Informasi ${ }^{2}$ \\ andripamungkas9@gmail.com,dedih@stmik-kharisma.ac.id \\ dwisumiardi@gmail.com
}

\begin{abstract}
ABSTRAKSI
E-Learning adalah bentuk pengembangan dari cara belajar konvensional (tatap muka) dengan memanfaat teknologi sebagai sarana pendukungnya. E-learning belakangan ini semakin maju dan berkembang seiring perkembangan teknologi informasi. Aksara Jawa atau yang lebih dikenal dengan nama Hanacaraka atau carakan merupakan salah satu dari sekian warisan budaya leluhur bangsa Indonesia. Dengan seiring perkembangan zaman, Aksara Jawa seolah menjadi salah satu warisan budaya yang terlupakan. Sebagai generasi muda Indonesia, sudah seharusnya kita melestarikan budaya bangsa yang merupakan peninggalan dari leluhur kita. Atas dasar itulah pada penelitian ini dikembangkan sebuah e-learning aksara jawa dengan metode index card match. Index cart match dipilih karena dapat dikembangkan dalam bentuk permainan pencocokan kartu, sehingga diharapkan dapat mengurangi tingkat kebosanan dan memudahkan mempelajarinya. Adapun materi yang akan di sajikan antara lain aksara carakan, aksara wilangan, aksara murda, aksara rekan, aksara pasangan dan sejarah aksara jawa. Untuk pengembangan perangkat lunak digunakan System Development life Cycle waterfall oleh Satzinger.
\end{abstract}

Kata kunci : E-Learning, Aksara jawa, Index Card Match dan System Development life Cycle waterfall

\section{Abstract}

E-Learning is a form of development of conventional learning (face-to-face) by utilizing technology as a means of support. E-learning lately more advanced and developed along the development of information technology. Javanese script or better known as Hanacaraka or carakan is one of the ancestral heritage of Indonesia. With the development of the times, Javanese script seems to be one of the forgotten cultural heritage. As a young generation of Indonesia, we should preserve the culture of the nation that is a relic of our ancestors. On that basis in this study developed an e-learning Javanese script with index card match method. The index cart match is chosen because it can be developed in the form of matching card game, so it is expected to reduce the level of boredom and make it easier to learn. The materials that will be served include aksara carakan, aksara wilangan, script murda, aksara colleagues, script pair and history of Javanese script. For the development of software used System Development life Cycle waterfall by Satzinger.

Keywords: E-Learning, Javanese script, Index Card Match and System Development life Cycle waterfall 


\section{PENDAHULUAN}

Perkembangan teknologi informasi semakin meluas dan mencakup segala aspek kehidupan manusia, tak terkecuali dalam bidang pendidikan. Seiring perkembangan zaman, inovasi dalam belajar mulai dikembangkan dengan berbasis teknologi. Dari sinilah teknologi mulai dikembangkan untuk menunjang pembelajaran. Salah satunya adalah E-Learning. E-Learning merupakan bentuk pengembangan dari cara belajar konvensional (tatap muka) dengan memanfaat teknologi sebagai sarana pendukungnya. Peranan teknologi dalam E-Learning sangatlah penting mengingat E-Learning merupakan pengembangan cara belajar yang melibatkan teknologi sebagai media pendukung. Hal ini dapat dimanfaatkan untuk melakukan peningkatan penguasaan materi dalam belajar karena dalam e-learning pembelajaran dapat ditampilkan dalam bentuk gambar, audio visual dan juga grafik.

Aksara jawa merupakan warisan budaya yang tidak ternilai harganya, aksara jawa yang dikenal juga dengan Hanacara semakin hari semakin lupakan. Meskipun begitu aksara jawa masih tetap di ajarkan sebagai muatan lokal. Materi yang disajikan pada E-Learning ini adalah sejarah aksara jawa, aksara carakan, aksara pasangan, aksara murda, aksara wilangan, aksara sandhangan, aksara rekan dan aksara swara. Materi tersebut adalah materi dasar mengingat target pengguna adalah pemula. Namun dalam pembelajaran aksara jawa ada kendala yang ditemui yaitu dalam hal mengingat bentuk, lafal pengucapan, serta kesalahan dalam menempatkan pasangan aksara Jawa. Untuk itu perlu adanya media dan metode yang tepat untuk mengatasinya. Salah satu konsep yang akan diusung adalah mengkombinasikan E-Learning dengan metode Index Card Match (ICM) untuk belajar aksara jawa.

Index Card Match merupakan cara menyenangkan lagi aktif untuk meninjau ulang materi pembelajaran. Cara ini memungkinkan siswa untuk berpasangan dan memberi pertanyaan kuis kepada temannya. ICM ini nantinya di adaptasi kedalam bentuk permainan mencocokan kartu. Metode ini diharapkan membuat belajar tidak lagi membosankan, sedangkan untuk menguji E-Learning ini akan dilakukan dilingkungan STMIK Kharisma Karawang. Ada banyak penelitian yang dilakukan tentang implementasikan metode ICM diantaranya, Susanti dkk (2014) dalam skripsinya yang berjudul Penggunaan Metode Index Card Match (ICM) dengan Media Kartu Gambar Dalam Meningkatkan Pembelajaran Bahasa Inggris Pada Siswa Kelas V SDN Pelasakan tahun Ajaran 2013/2014, metode ICM ini terbukti efektif dalam meningkatkan pembelajaran Bahasa Inggris Pada Siswa Kelas V SDN Pelasakan tahun Ajaran 2013/2014. Kemudian Asnimar dan baskara (2013), dalam skripsi Penerapan Metode Pembelajaran Aktif Index Card Match (ICM) Untuk Peningkatan Hasil Belajar Ekonomi Siswa Kelas XI IPS SMAN 6 Pekanbaru Tahun ajaran 2012/2013 menyatakan bahwa mengimplementasikan metode pembelajaran aktif Index Card Match (ICM) dalam proses pembelajaran dapat meningkatkan hasil belajar IPS siswa dari skor dasar ke siklus pertama yaitu dari rata-rata $78,5 \%$ menjadi $86,16 \%$ dengan peningkatan sebesar 7,66\% dan peningkatan hasil belajar dari siklus pertama ke siklus kedua yaitu rata-rata $86,16 \%$ menjadi $90 \%$ dengan peningkatan sebesar $3,84 \%$, sehingga dapat di simpulkan bahwa ICM mampu meningkatkan hasil belajar dan meningkatkan pemahaman siswa. Serta Umaryanti (2009) dalam skripsinya yang berjudul Menerapkan Metode Pembelajaran Index Card Match (Mencari Pasangan) Untuk Meningkatkan Prestasi Belajar Siswa Kelas VIII E SMP Negeri 1 Subah Kabupaten Batang menyimpulkan bahwa mengimplementasikan model index card match dapat meningkatkan keaktifan siswa dalam belajar begitupun dengan prestasinya. Metode pengembangan sistem yang akan digunakan metode pendekatan System Development Life Cycle (SDLC) waterfall [10] berbasis Object Oriented Programing (OOP). ELearning ini dibuat berbasiskan web menggunakan metode Index Card Match (ICM) dengan bahasa pemrograman PHP dan media penyimpanan data menggunakan basisdata MySql serta metode pengembangan sistem menggunakan SDLC waterfall berbasis OOP. Materi yang akan disajikan adalah sejarah aksara 
jawa, aksara carakan, aksara pasangan, aksara murda, aksara wilangan, aksara sandhangan, aksara rekan dan aksara swara .

\section{METODE PENELITIAN}

\section{Bahan Penelitian}

Bahan penelitian diperoleh dari berbagai macam studi literatur maupun data dan pengamatan langsung. Bahan penelitian ini yang dijadikan sebagai bahan rujukan dalam melakukan penelitian sehingga dapat menguatkan analisis serta pemecahan masalah yang dihadapi dalam penelitian ini. Bahan penelitian yang digunakan untuk penelitian buku, ebook serta jurnal penelitian serta pengamatan. Semua literatur tersebut merujuk pada pembahasan tentang e-learning, aksara jawa dan juga index card match serta tentang bahasa pemograman dan perangkat lunak yang digunakan.

\section{SDLC waterfall}

Metode penelitian yang digunakan untuk membangun sistem ini adalah SDLC waterfall, karena tahapannya berurutan dan tiap tahapannya baru bisa dilanjutkan ke tahap selanjutnya setelah tahap sebelumnya selesai. Menurut Satzinger SDLC waterfall meliputi beberapa phase yaitu project planning phase, analysis phase, design phase, implementation phase dan support phase yang ditunjukan pada gambar dibawah ini :

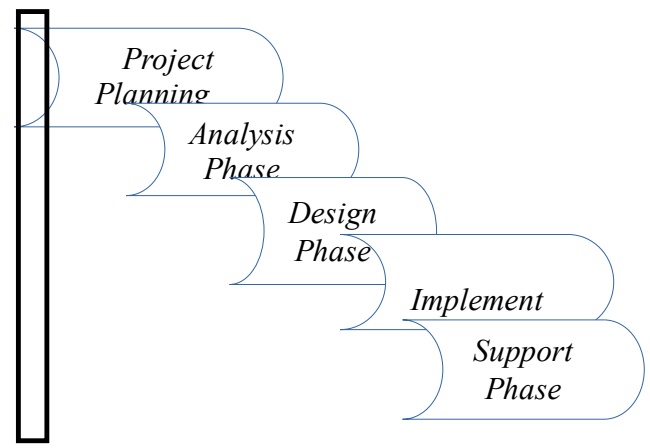
Gambar 1. SDLC Waterfall (Satzinger et al, 2010)

\section{Project Planning Phase}

Tahapan ini dilakukan penelitian terlebih dahulu untuk menyaring data serta informasi yang terkait, yaitu melakukan teknik dengan cara mengidentifikasi masalah, pengumpulan data, menganalisis teori, pembuatan jadwal, mencari solusi dan mengidentifikasi kebutuhan.

Tabel 1. Rincian project planning phase

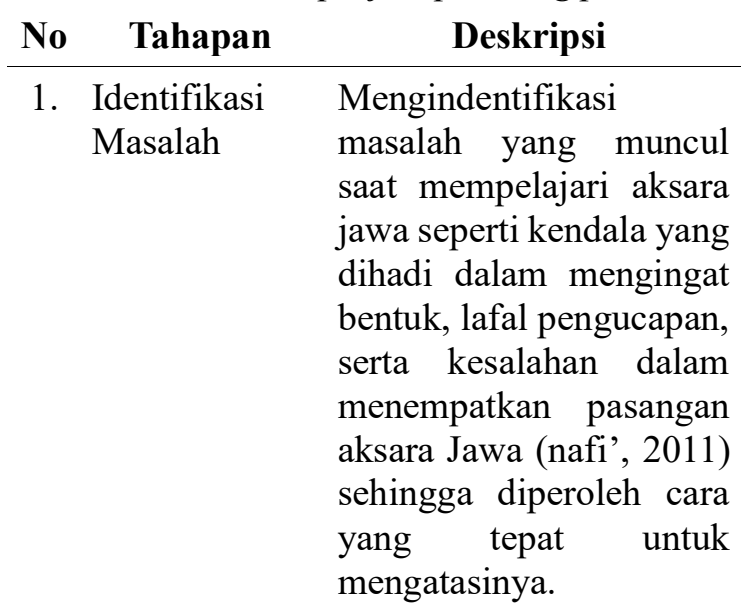

2. Pengumpulan Melakukan Studi literatur Data melalui jurnal-jurnal penelitian sebelumnya dan buku-buku yang berhubungan dengan $e$ learning, aksara jawa dan juga index card match.

3. Menganalisis Melakukan analisa dari Teori berbagai macam sumber dan literatur terkait $E$ Learning untuk mempelajari aksara jawa dengan implementasi Index Card

4. Pembuatan Membuat rancangan Jadwal rencana berjangka pembuatan aplikasi $E$ Learning untuk mempelajari aksara jawa dengan implementasi Index Card Match.

5. Mencari Solusi
Membuat sistem yang dapat digunakan untuk membantu dalam mempelajari aksara jawa 


\begin{tabular}{|c|c|c|}
\hline No & Tahapan & Deskripsi \\
\hline & & $\begin{array}{lr}\text { yaitu sebuah elearning } \\
\text { berbasis web dengan } \\
\text { menggunakan metode } \\
\text { index card match. }\end{array}$ \\
\hline & $\begin{array}{l}\text { Mendefinisik } \\
\text { an Kebutuhan }\end{array}$ & $\begin{array}{l}\text { Menetukan alat maupun } \\
\text { bahan yang dibutuhkan } \\
\text { baik software maupun } \\
\text { hardware } \\
\text { membangun untuk } \\
\text { pendukung keputusan. }\end{array}$ \\
\hline
\end{tabular}

Analysis Phase

1. Analisis Proses index card match

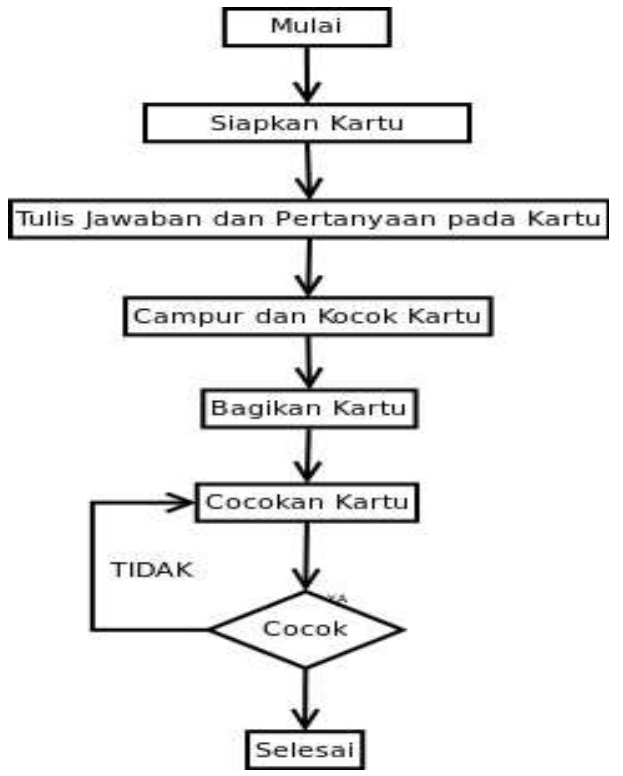

Gambar 2. Analisis Proses index card match

\section{Analisis Sistem}

Tahapan ini yaitu mempelajari sistem yang ada dan menganalisis bidang masalah dengan menggunakan Object Oriented Programing (OOP), sehingga dapat diperoleh dari pemahaman menyeluruh terhadap masalahmasalah serta manfaat yang akan diperoleh. Adapun tahapan dari analisis tersebut yaitu:

1. System activities (deskripsi use case, aktor, skenario, dan use case diagram).

2. Class diagram (class definition dan class relation).

3. Object interaction (sequence diagram)

4. Object behavior (activity diagram).

\section{Design Phase}

Setelah proses analisa selesai dilakukan selanjutnya tahapan desain yang dilakukan. Dalam tahapan ini desain yang dilakukan oleh peneliti adalah pendesainan berbasis Object Oriented Design (OOD) terdiri dari :

a. Desain proses.

b. Desain antarmuka.

\section{Implementation Phase}

Tahapan ini yaitu untuk membangun, menguji, dan menginstal sistem pendukung keputusan yang handal dengan pengguna yang terlatih siap untuk mendapatkan keuntungan seperti yang diharapkan dari pengguna sistem. Pada tahapan ini dilakukan beberapa tahapan, antara lain:

1. Instalasi Sistem

2. Pelatihan Prosedural

3. Pengujian Sistem Komputer (pengujian white box dan black box)

\section{Support Phase}

Tahap pendukung atau pemeliharaan dilakukan pengecekan terhadap sistem dalam jangka waktu tertentu. Selanjutnya pemeliharaan sistem dilakukan ketika ada laporan dari pihak pengguna di tempat penelitian melalui telepon atau pesan singkat seluler mengenai adanya kesalahan terhadap sistem yang telah di terapkan yang selanjutnya akan dilakukan tindakan penanganan terhadap sistem yang mengalami kesalahan.

\section{HASIL DAN PEMBAHASAN}

\section{Hasil Project Planning Phase}

Tahapan Project Planning Phase yang dilakukan telah di diperoleh berbagai macam rincian hasil Penelitian. Adapun hasilnya adalah sebagai berikut :

Tabel 2. Hasil Project Planning Phase

\begin{tabular}{llll}
\hline No & Tahapan & \multicolumn{2}{c}{ Hasil } \\
\hline 1. & Identifikasi & Adanya kesulitan yang \\
& Masalah & di alami & dalam \\
& & mempelajari & aksara \\
& & jawa terutama dalam \\
& & mengingat bentuk dan
\end{tabular}




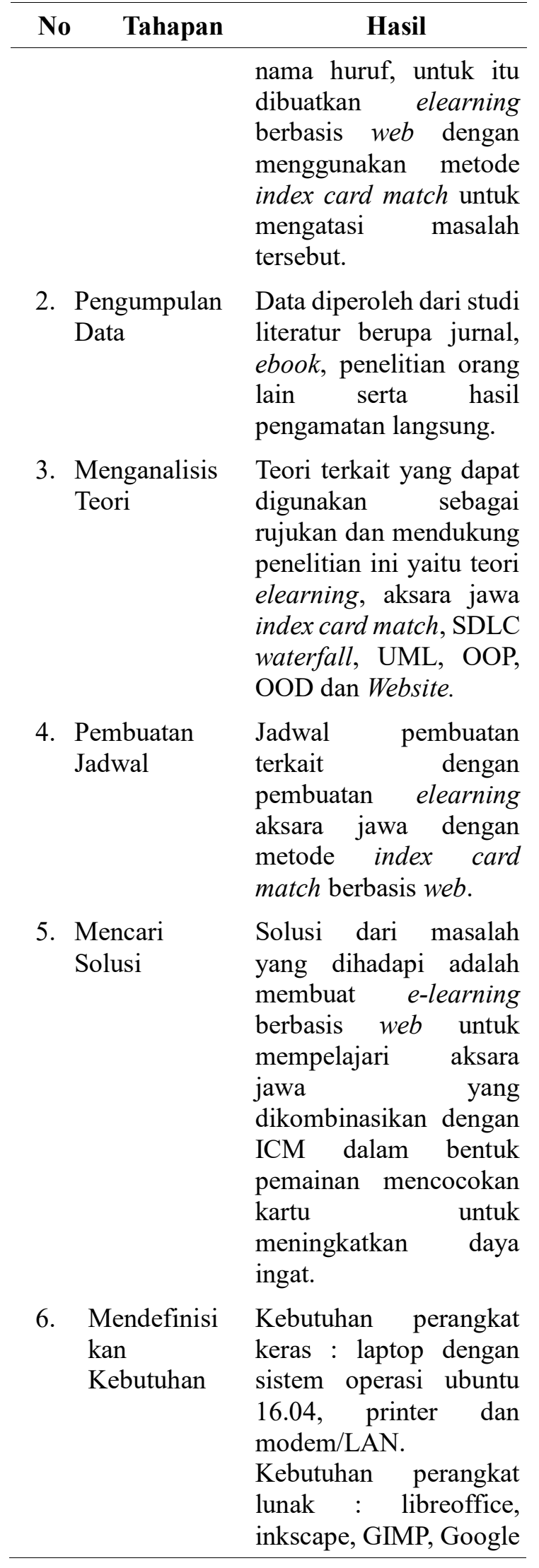

\begin{tabular}{lllr}
\hline No & Tahapan & \multicolumn{2}{c}{ Hasil } \\
\hline & $\begin{array}{l}\text { Chrome, } \\
\text { diagram } \\
\text { hosting }\end{array}$ & dan wa dia \\
\end{tabular}

\section{Hasil Analysis Phase}

\section{Hasil Analisis Index Card Match (ICM)}

Analisis yang telah dilakukan terkait masalah yang dihadapi yaitu kesulitan dalam mengingat bentuk aksara jawa untuk itu diperlukan cara yang tepat untuk mengatasi hal tersebut. Dalam penelitian ini peneliti mencoba membuat media pendukung untuk pembelajaran aksara jawa berupa elearning berbasis web dengan metode index card match. Metode index card match mempunyai langkah-langkahnya adalah sebagai berikut :

a. Pada kartu indeks yang terpisah tulislah pertanyaan apapun yang dituliskan dikelas. Buatlah kartu pertanyaan dalam jumlah yang sama dengann setengah jumlah siswa.

b. Pada kartu yang terpisah, tulislah jawaban atas masing-masing pertanyaan itu.

c. Campurkan dua kumpulan kartu itu dan kocoklah beberapa kali agar tercampur aduk.

d. Berikan satu kaartu untuk satu siswa. Jelaskan bahwa ini adalah latihana mencocokan. Sebagian siswa mendapatkan pertanyaan tinjauan dan sebagian lagi mendapatkan kartu jawaban.

e. Perintahkan siswa untuk mencari kartu pasangan mereka. Bila sudah terbentuk pasangan, perintahkan siswa yang berpasangan untuk mencari tempat duduk yang sama.

f. Bila semua pasangan yang cocok telah duduk bersama, perintahkan setiap pasangan untuk memberikan kuis jepada siswa yang lain dengan membacakan keras-keras pertanyaan mereka dan menantang siswa lain untuk memberikan jawabannya.

Prosedur di atas digunakan dalam penerapan ICM secara manual yaitu belum melibatkan/berbasis web seperti yang akan di kembangkan sekarang. Untuk dapat di Implementasikan dalam bentuk permainan berbasis web, maka dibutuhkan beberapa penyesuaian dari bentuk aslinya. Adapun 
prosedurnya akan berubah menjadi sebagai berikut :

1. Pilih kartu A

2. Kartu A terbuka

3. Pilih Kartu B

4. Kartu B terbuka

5. Jika kartu A dan kartu B sama maka kartu akan menghilang

6. Jika kartu A dan kartu B berbeda maka kartu akan tertutup lagi

7. Jika kartu masih ada maka pilih kartu lagi

8. Jika kartu habis maka permainan selesai

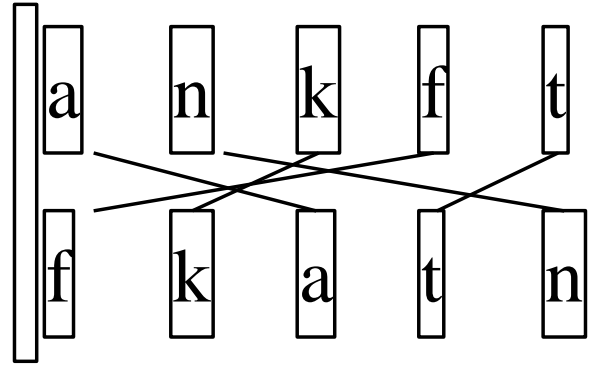

Gambar 3. Ilustrasi Index card match

Gambar 3 mengilustrasikan index card match dimana yang harus dilakukan adalah mencocokan masing-masing kartu yang ada. Dalam penelitian ini metode index card match akan di aplikasikan dalam permainan mencocokan kartu berbasis web sehingga tidak lagi dilakukan secara manual. Jadi selain materi yang disajikan dalam elearning ini, pengguna juga dapat mengasah daya ingat dengan memainkan permainan mencocokan kartu yang berisi aksara jawa. Permainan ini di adaptasi dari metode index card match yang dimodifikasi kedalam permainan mencocokan kartu berindeks berbasis web.

Metode index card match yang digunakan dalam elearning ini, di manfaatkan untuk mengasah daya ingat dengan memainkan permainan mencocokan kartu yang berisi aksara jawa. Permainan ini di adaptasi dari metode index card match yang dimodifikasi kedalam permainan mencocokan kartu berindeks berbasis web. Untuk prosedurnya digambarkan dalam bentuk flowchart seperti dibawah ini :

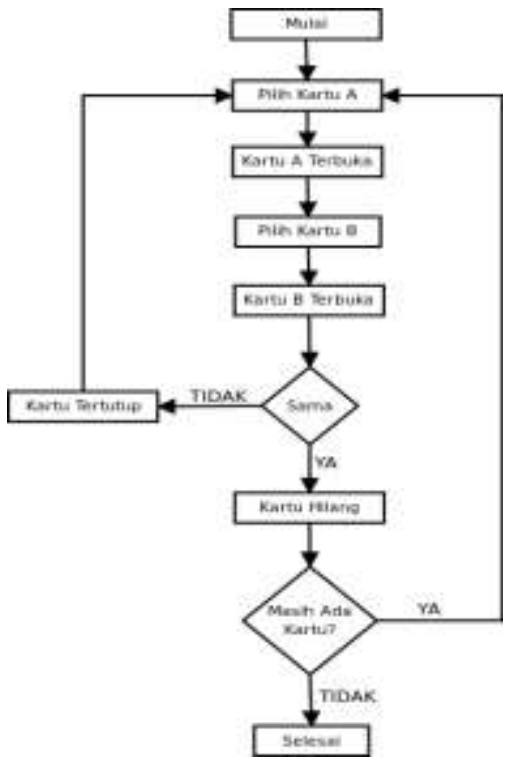

Gambar 4. Prosedur index card match berbasis web

\section{Analisis Sistem}

a) Actor Discription

Adapun untuk aktor terdiri dari tiga, yaitu admin,pengajar dan pelajar.

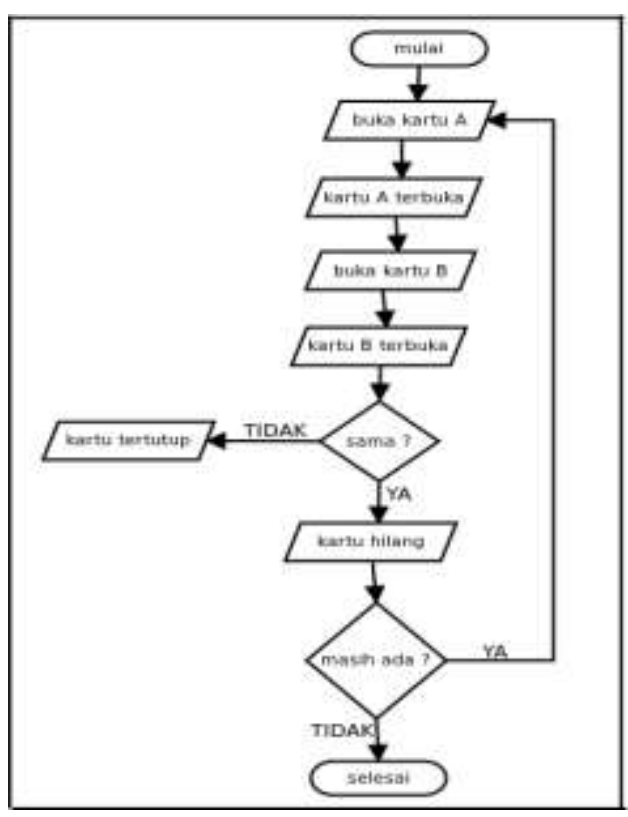

Gambar 5. Actor Description 


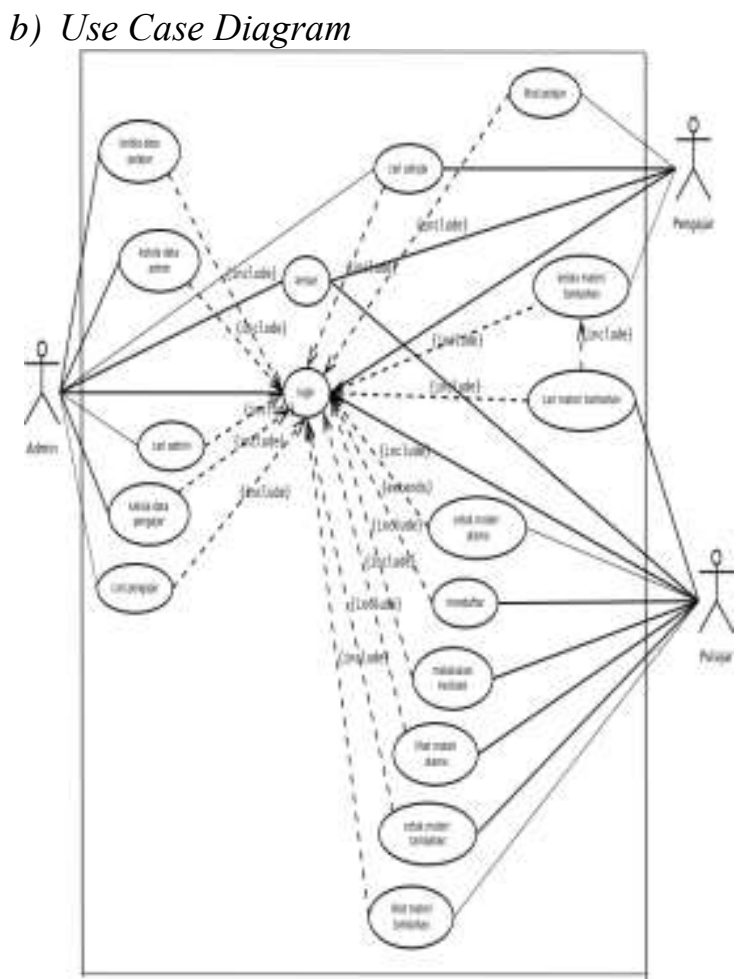

Gambar 6. Use Case Diagram

\section{c. Skenario use case}

Skenario Use Case terdiri dari Kelola Data Admin, Kelola Data Pengajar, Kelola Data Pelajar, Login, Keluar, Melakukan evaluasi, Kelola materi tambahan, Cari pelajar, Cari materi tambahan, Cetak Materi Utama, Cetak Materi Utama, Lihat materi tambahan, Lihat pengajar, Lihat pelajar, Mendaftar, Cari Admin, Cari Pengajar.

Tabel 3. Skenario use case evaluasi

\begin{tabular}{ll}
\hline \multicolumn{1}{c}{$\begin{array}{c}\text { Nama Use } \\
\text { Case }\end{array}$} & \multicolumn{1}{c}{ Evaluasi } \\
\hline Skenario & Menampilkan halaman evaluasi \\
Pemicu Event & $\begin{array}{l}\text { Aktor memilih menu evaluasi } \\
\text { kemudian masuk kedalam }\end{array}$ \\
& halaman evaluasi. \\
Deskripsi & $\begin{array}{l}\text { Aktor melakukan evaluasi } \\
\text { Singkat }\end{array}$ \\
& $\begin{array}{l}\text { untuk mengetahui tingkat daya } \\
\text { disajikan pada halaman materi } \\
\text { utama dan materi tambahan. }\end{array}$
\end{tabular}

Aktor

\begin{tabular}{|c|c|}
\hline $\begin{array}{l}\text { Nama Use } \\
\text { Case }\end{array}$ & Evaluasi \\
\hline Stakeholder & Admin,pengajar dan pelajar \\
\hline $\begin{array}{l}\text { Kondisi } \\
\text { Sebelum }\end{array}$ & - \\
\hline $\begin{array}{l}\text { Kondisi } \\
\text { Sesudah }\end{array}$ & $\begin{array}{l}\text { Menampilkan hasil evaluasi } \\
\text { berupa tingkat daya ingat } \\
\text { pelajar }\end{array}$ \\
\hline \multirow{3}{*}{$\begin{array}{l}\text { Aliran } \\
\text { Aktifitas }\end{array}$} & Aksi aktor \\
\hline & $\begin{array}{l}\text { Aktor memilih Menampilkan halaman } \\
\text { menu evaluasi evaluasi. }\end{array}$ \\
\hline & $\begin{array}{ll}\text { Aktor memilih Kartu terbuka, apabila } \\
\text { sepasang kartu kartu sama maka akan } \\
\text { yang sama } & \text { hilang, jika tidak kartu } \\
& \text { akan tertutup kembali. } \\
& \text { Aktor akan memilih } \\
& \text { kartu lagi jika kartu } \\
& \text { masih tersisa, jika tidak } \\
& \text { permainan akan selesai } \\
& \text { dan akan menampilkan } \\
& \text { hasil evaluasi. }\end{array}$ \\
\hline
\end{tabular}

Kondisi

Kesalahan

\section{d. Class Diagram}

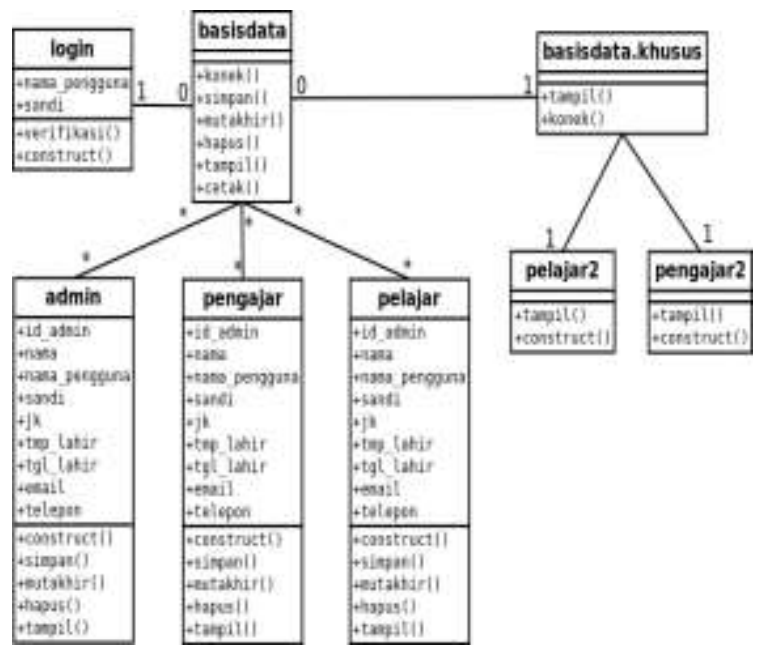

Gambar 7. Class diagram 
e. Object interaction (Sequence diagram)

Object interaction (Sequence diagram) terdiri dari Kelola Data Admin, Kelola Data Pengajar, Kelola Data Pelajar, Login, Keluar, Melakukan evaluasi, Kelola materi tambahan, Cari pelajar, Cari materi tambahan, Cetak Materi Utama, Cetak Materi Utama, Lihat materi tambahan, Lihat pengajar, Lihat pelajar, Mendaftar, Cari Admin, Cari Pengajar.

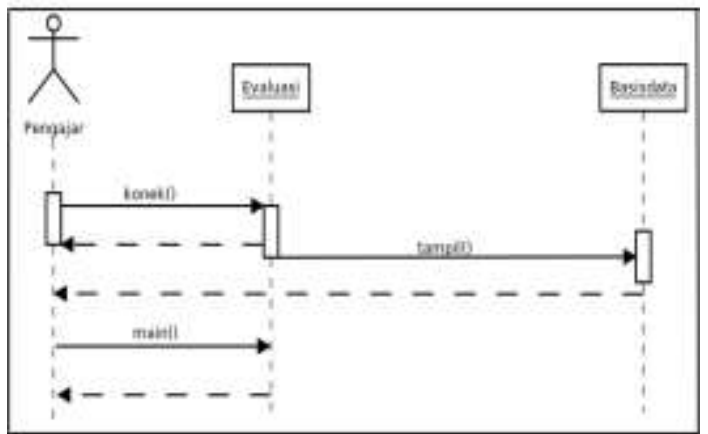

Gambar 8. Object interaction (Sequence diagram)

\section{F. Object behavior (Activyti diagram)}

Object behavior terdiri dari Kelola Data Admin, Kelola Data Pengajar, Kelola Data Pelajar, Login, Keluar, Melakukan evaluasi, Kelola materi tambahan, Cari pelajar, Cari materi tambahan, Cetak Materi Utama, Cetak Materi Utama, Lihat materi tambahan, Lihat pengajar, Lihat pelajar, Mendaftar, Cari Admin, Cari Pengajar.

\subsection{Hasil Design Phase}

a. Desain Proses

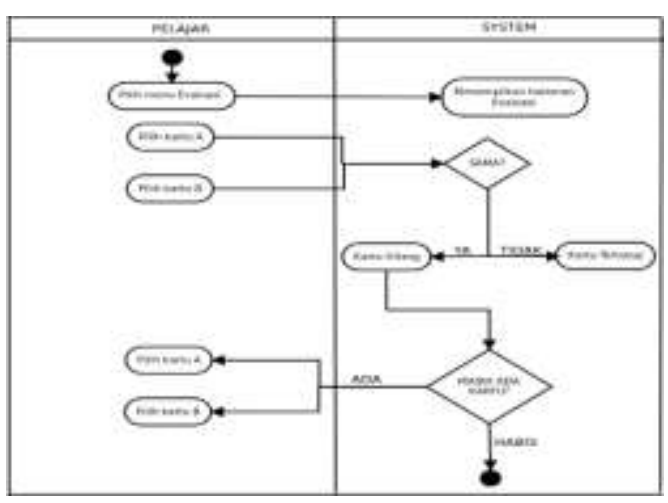

2. Desain Interface

a. login

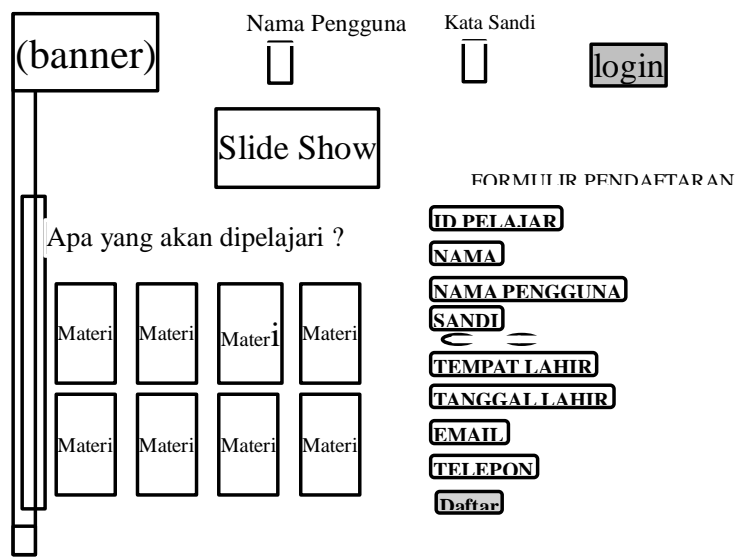

Gambar 10. Desain interface login b. Evaluasi

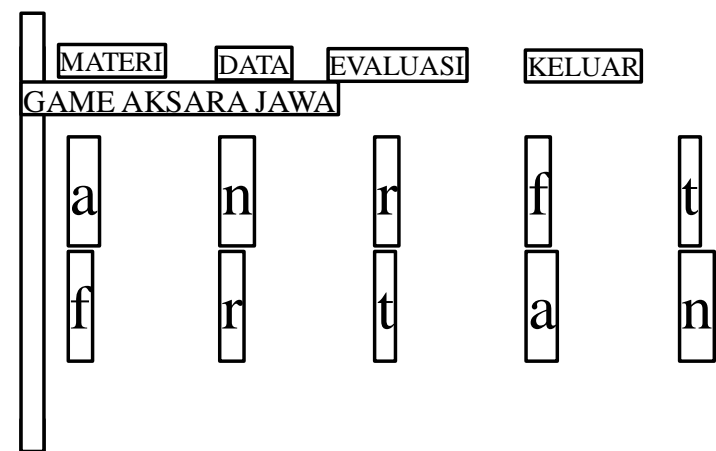

Gambar 11. Desain interface evaluasi

\subsection{Implementation Phase}

1. Tampilan halaman evaluasi

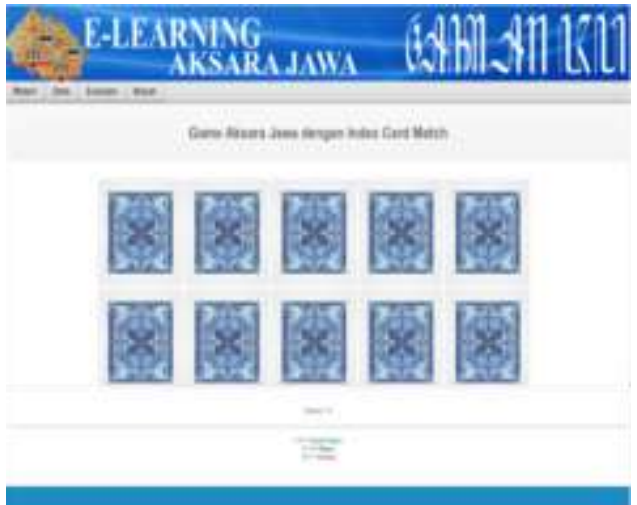

Gambar 12. Tampilan Halaman Evaluasi

Gambar 9. Desain Proses 


\section{KESIMPULAN DAN SARAN}

\section{Kesimpulan}

Dari penelitian yang telah dilakkukan makan dapat di simpulkan bahwa elearning aksara jawa dapat dibuat dengan metode index card match dan berbasis web.

\section{Saran}

Berdasarkan hasil penelitian, maka peneliti merekomendasikan atau menyarankan beberapa hal mengenai elearning aksara jawa sehingga dalam pengembangan dapat lebih baik yaitu dengan:

1. Menggunakan bahasa pemograman lain sehingga dapat menambah variasi bahasa pemograman yang di gunakan dan mengetahui kelebihan dan kekurangannya.

2. Mengimplementasikan metode lain hal ini bertujuan untuk lebih memudahkan pengguna dalam menyerap materi yang ada pada elearning khususnya aksara jawa.

3. Menggunakan metode pengembangan sistem yang lain, dalam penelitian ini menggunakan metode pengembangan sistem SDLC waterfall dan penelitian selanjutnya diharapkan dapat menggunakan metode pengembangan sistem yang lain.

4. Gunakkan pokok bahasan yang lain karena dalam elearning ini pokok bahasanya adalah aksara jawa pengembangan kedepannya dapat menggunakan pokok bahasan yang lain karena ada banyak bahasan yang dapat di implementasikan pada elearning

\section{Daftar Pustaka}

Asnimar dan Baskara Agus . 2013. Penerapan Metode Pembelajaran Aktif Index

Card Match (ICM) Untuk

Peningkatan Hasil Belajar Ekonomi Siswa Kelas XI IPS

SMAN 6 Pekanbaru Tahun ajaran 2012/2013. jurnal. Pendidikan

Ekonomi Akuntansi FKIP UIR.

BOC Indonesia. 26 November 2007. Pengertian Website, Web Hosting dan Domain Name
(Online). Website:

http://www.boc.web.id/pengertianwebsite-webhosting-domainnamel. (Diakses pada tanggal 25 Juli 2017).

Galin, Daniel. 2004. Softrwere Quality Assurance. Person Education Limited, England

Horton William and Horton Katherine. 2003. ELearning Tools and Technologies : A consumer guide for trainers, teachers, educators, and instructional designers. USA : Wiley Publishing, Inc.

Jogiyanto. 2001. Analisis dan Desain Sistem Informasi: Pendekatan Terstruktur Teori dan Praktik Aplikasi Bisnis. Andi : Yogyakarta.

Nafi’ Marfuatun Lutfi Khusnul. 2011. "Media Pembelajaran Aksara Jawa Berbasis Multimedia Interaktif Menggunakan Macromedia Flash 8". jurnal. Fakultas Teknik Universitas Negeri Yogyakarta, Yogyakarta.

Nursalam dan Efendi Ferry. 2008. Pendidikan dalam Keperawatan. Jakarta: Salemba Medika.

Pranoto Alvini. 2009. Sains dan Teknologi. Jakarta: PT Gramedia Pustaka Utama.

Sidik Betha. 2017. Pemograman Web dengan PHP7. Informatika. Bandung

Satzinger, John W, Jackson, Robert B, dan Burd, Stephen D. 2010. System analysis and design in a changing world, fifth edition. Course Technology,

Boston

Silberman, Mel, 1996, Active Learning: 101 Strategies to Teach Any Subject,

Boston: Allyn \& Bacon. Edisi Revisi. Diterjemahkan Oleh: Muttaqien Raisul. Jakarta: Nusamedia.

S, Rosa A. dan Shalahuddin M. 2015. Rekayasa Perangkat Lunak Terstruktur dan Berorientasi Objek. Informatika. Bandung.

Susanti Tri, Wahyudi, Suhartono, 2014. Penggunaan Metode Index card Match (ICM) Dengan Media Kartu Gambar dalam Peningkatan Pembelajaran Bahasa Inggris Pada Siswa Kelas V SDN Pelasakan Tahun Ajaran 2013/2014[skripsi]. PGSD FKIP 
Universitas Sebelas Maret, Jl. Kepodang 67A Panjer, Kebumen.

Umaryanti Yuni. 2009. Penerapan Model

Pembelajaran Index Card Match (ICM)

Untuk Meningkatkan Prestasi Belajar

Siswa Kelas VIII E SMP Negeri 1 Subah

[Skripsi]. Univesitas Negeri Semarang.

Undang-Undang Republik Indonesia Nomor 20

Tahun 2003 Tentang Sistem Pendidikan Nasional.

Wahyuningsih dian dan Makmur Rahmat. 2017.

E-Learning Teori dan Aplikasi.

Informatika. Bandung 